Larysa Borysivna Bondarenko®, Ganna Mykhailivna Shayakhmetova ${ }^{\circ}$, Alla Kostyantynivna Voronina $\odot$, Valentina Mykolaivna Kovalenko

SI "Institute of Pharmacology \& Toxicology National Academy of Medical Sciences of Ukraine", Kyiv, Ukraine

\title{
Losartan effects on liver cytochromes CYP3A, CYP2C and CYP2E1 functioning at metabolic syndrome in young and adult rats
}

Corresponding author:

Larysa Borysivna Bondarenko SI "Institute of Pharmacology \& Toxicology National Academy of Medical Sciences of Ukraine", Antona Tzedika str.14, 03680 Kyiv, Ukraine

email: larabon04@yahoo.com

Medical Research Journal 2019; Volume 4, Number 2, 72-79 10.5603/MRJ.a2019.0009 Copyright (C) 2019 Via Medica ISSN 2451-2591

\begin{abstract}
CYP450-dependent interactions and toxicological consequences of hypoglycemic and antihypertensive drugs used in treatment of children with metabolic syndrome (MS) remained unclear. Our aim was to carry out a complex estimation of metabolic syndrome and losartan mediated changes in CYP3A, CYP2C, CYP2E1 mRNA expression, corresponding marker enzymes activities, liver antioxidant system and lipid peroxidation parameters of adult and pubertal rats. Wistar albino male rats of two age categories (young animals of 21 days age (50-70 g) and adults (160-180 g) were divided into 6 groups (6 animals in each): 1 - Control 1 (intact young rats); 2 - Control 2 (intact adult rats); 3 -young rats with MS; 4 - adult rats with MS; 5 - young rats with MS+losartan; 6 - adult rats with MS + losartan. The metabolic syndrome model was induced by full replacement of drinking water with $20 \%$ fructose solution (200 g/l). After 60 days of MS modeling, investigation of rat liver CYP3A, CYP2C, CYP2E1 mRNA expression, their marker enzymes activities, lipid peroxidation parameters were carried out. Losartan administration caused increase of CYP3A, CYP2C and CYP2E1 mRNA expression rates in both age groups. Marker enzymes, glutathione transferase and reductase rates were normalized only in adult rats. In group of pubertal animals losartan administration led to CYP3A and CYP2C marker enzymes activities normalization. Liver reduced glutathione contents remained decreased in both age groups. Thus, losartan demonstrates some age-dependent effectiveness towards normalization of CYP450 isoforms expression rates, $\mathrm{p}$-nitrophenol hydroxylase, erythromycin- $\mathrm{N}$-demethylase and diclofenac hydroxylase activities, but not glutathione system and lipid peroxidation rates.

Key words: metabolic syndrome, losartan, CYP450, pubertal, rats
\end{abstract}

Med Res J 2019; 4 (2): 72-79

\section{Introduction}

Metabolic syndrome (MS) belongs to pathological states that could affect CYP450 activity. It is modern medicine's actual problem caused by an unhealthy lifestyle. Last decades MS is increasingly spreading among children and adolescents [1]. An emerging epidemic of pediatric hypertension is paralleled an increasing prevalence of childhood obesity. Elevated blood pressure during childhood and adolescence is associated with end-organ damage [1].

Already available clinical data highlight that pediatric drug dosing, safety and efficacy cannot simply be extrapolated from adult clinical trials [1]. Particularly interesting is the study of the joint effect of metabolic syndrome and drugs designed to correct its symptoms. In this case, it is possible to identify possible additional modifying factors for drugs biotransformation with this pathology. Unfortunately, the information dedicated to this issue is extremely limited [2,3]. There are no data on CYP450-dependent interactions of hypoglycemic and antihypertensive drugs used in the treatment of MS in children and adolescents and no detailed analysis of their use toxicological consequences. Our preliminary results indicate the presence of certain dependencies of CYP3A, CYP2C and CYP2E1 levels on age at MS [4].

Losartan was the first among angiotensin receptor blockers approved for pediatric hypertension by the United States FDA in 2004 following completion of the required clinical trials [1]. According to data obtained in vitro losartan is metabolized mainly via CYP3A and CYP2C isoforms of CYP450 [5, 6]. But there are no 
data on its effects on CYP450 isoforms in children and adolescents with MS.

The aim of this work was to study the joint effects of MS and losartan on hepatic CYP3A, CYP2C, CYP2E1 mRNA expression, their marker enzymes, liver antioxidant system and lipid peroxidation of adult and pubertal rats with MS.

\section{Materials and methods}

A total of 36 Wistar albino male rats of two age categories (young animals of 21 days age $(50-70 \mathrm{~g})$ and adults (160-180g)) were used in the study. They were kept under a controlled temperature (from $22{ }^{\circ} \mathrm{C}$ to $\left.24{ }^{\circ} \mathrm{C}\right)$, relative humidity of $40 \%$ to $70 \%$, lighting $(12 \mathrm{~h}$ light-dark cycle), and on a standard pellet feed diet ("Phoenix" Ltd., Ukraine). The study was performed in accordance with the recommendations of the European Convention for the Protection of Vertebrate Animals used for Experimental and other Scientific Purposes and approved by the Institutional Animal Care and Use Committee. The model of metabolic syndrome was reproduced according to the protocol of Abdulla et al. [7]. Young and adult animals were divided into 6 groups (6 animals in each group): 1 - Control 1 (intact young rats), 2-Control 2 (intact adults), 3-MS3 (young rats with MS), 4 - MS4 (adult rats with MS), 5 - MS3+losartan (young rats with MS and losartan $(4,43 \mathrm{mg} / \mathrm{kg}$ of body weight, per os, 60 days)), 6 - MS4+ losartan (adult rats with MS and losartan treatment). MS was induced by full replacement of drinking water with $20 \%$ fructose solution $(200 \mathrm{~g} / \mathrm{l})$.

Crystalline D-fructose > 99\% (Khimlaborreactiv, Ukraine, series 072000897834 , batch XW 130105) was used in experiments. $20 \%$ fructose was prepared daily and given every day for two months ad libitum. In our experiments, losartan (potassium losartan, manufactured by LLC "KUSUM PHARM", Sumy, Ukraine) was used.

After 60 days of $20 \%$, fructose solution consumption and losartan treatment rats were sacrificed under mild ether anaesthesia by decapitation.

Post mitochondrial and microsomal fractions of livers were obtained by the method of Kamath et al. [8], and aliquots were kept frozen at $-70^{\circ} \mathrm{C}$ until needed.

We investigated changes of rat orthologs of human cytochromes P-450: CYP2E1, CYP3A2 instead of CYP3A4 [9] and CYP2C23 instead of CYP2C9 and CYP2C19 [10]. p-Nitrophenol (PNP) hydroxylase activity (a selective enzyme marker for CYP2E1) was determined in a microsomal fraction of liver according to the method of Koop et al. [11]. Erythromycin $\mathrm{N}$-demethylase activity (a selective enzyme marker for CYP3A) was determined in liver microsomal fraction according to the method of Wang et al. [12], diclofenac hydroxylase activity (a selective enzyme marker for
CYP2C) - according to the method of Necrasova et al. [13]. Glutathione-S-transferase activity was determined in liver post mitochondrial fraction according to the method of Habig et al. [14], glutathione reductase activity - in microsomes in accordance with „Current Protocols in Toxicology" [15], reduced glutathione and proteins $\mathrm{SH}$-groups contents - in liver homogenates by method of Sedlak with Ellman's reagent [16]. Protein contents were determined with Total Protein Kit, Micro Lowry, Onishi \& Barr Modification (Sigma-Aldrich, Ink., USA).

The rats' livers were used for investigation of cytochrome P-450 isoforms mRNA expression rates by method of reversed transcriptase polymerase chain reaction ( $\mathrm{rPCR}$ ). Isolation of total mRNA was carried out with TRI-Reagent (Sigma, USA). Synthesis of cDNA was carried out with reagents and protocol of Fermentas (Germany). rPCR reaction mixture contents, specific primers for CYP2E1 gene amplification (forward 5'-CTTCGGGCCAGTGTTCAC-3' and reverse 5'- CCCATATCTCAGAGTTGTGC-3'), as well as amplification protocol were chosen according to Lankford et al. [17]. rPCR reaction mixture, amplification protocol and following specific primers - forward 5'-TACTACAAGGGCTTAGGGAG-3' and reverse 5'- CTTGCCTGTCTCCGCCTCTT-3' were used for CYP3A2 gene amplification according to Jager et al. [9]. rPCR reaction mixture, amplification protocol and following specific primers - forward 5'-GATGCTGTCTTCCGTCATGC-3' and reverse 5'- GTAATAGGCTTGATGTCAAG-3' were used for CYP2C23 gene amplification according to Imaoka et al. [10]. rPCR with primers of $\beta$-actin (sense 5'-GCTCGTCGTCGACAACGGCTC-3' and antisense 5'-CAAACATGAT CTGGGTCATCTTCT-3') was carried out for internal control. All primers were synthesized by «Metabion» (Germany). Thermocycler MyCycler (BioRaD, USA) was used for amplification. Electrophoresis of PCR products (CYP2E1-744 b.p., CYP2C23-252 b.p., CYP3A2 - 349 b.p. and $\beta$-actin-353 b.p.) was carried out in $2 \%$ agarose gels $(80 \mathrm{~V} ; 1.5 \mathrm{~h})$. After electrophoresis gels were stained with ethidium bromide and visualized under a UV transilluminator (BIORAD, USA). Electrophoresis data analysis was carried out with Quantity One Software (USA).

The levels of lipid peroxidation (LPO) in liver microsomes were investigated as the rates of NADPH-dependent thiobarbituric acid reactive substances (TBARS) formation [18].

\section{Results}

CYP2E1 mRNA expression comparative study in the livers of pubertal and adult rats with MS and losartan administration demonstrated pronounced changes at both age groups of rats (Fig. 1). 


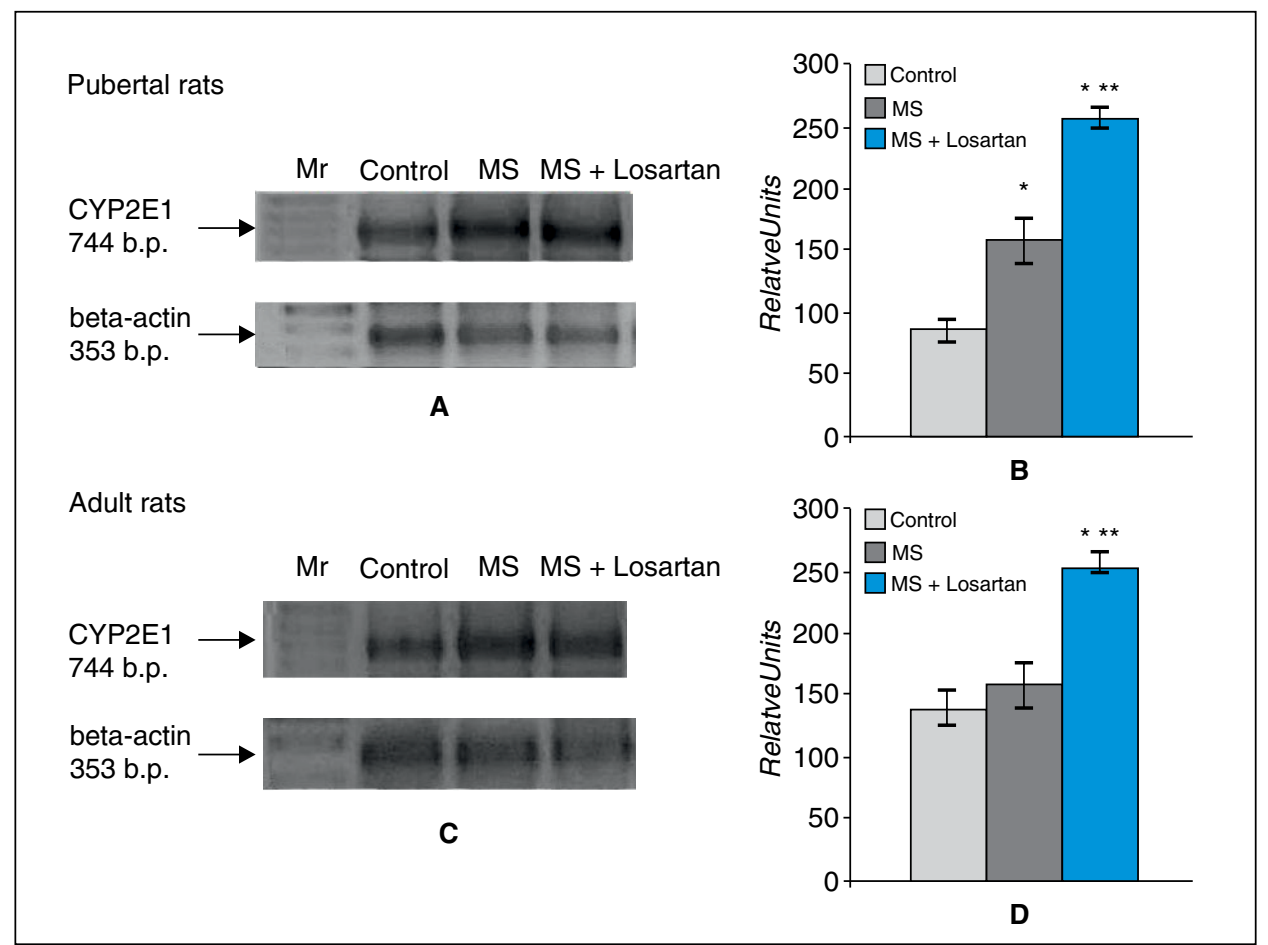

Figure 1. CYP2E1 mRNA content in the liver of pubertal and adult rats with MS and losartan administration: A, C - representative electrophoregrams of CYP2E1 (744 b.p) and reference-gene $\beta$-actin (353 b.p.) RT-PCR products; B, D - average rate of CYP2E1 mRNA expression in the liver $(\mathrm{n}=6, \mathrm{Mr}$ - DNA marker, signal intensity of $\beta$-actin was taken as $100 \%)$; $P<0.05$ in comparison with control; ** $P<0.05$ in comparison with MS

CYP2E1 mRNA expression was increased at a group of pubertal animals with MS (1.8 folds compared with the control) and the group of pubertal animals with MS and losartan administration (more than 2.0 folds compared with the control). Losartan, administered to adult animals with MS, resulted in 2-2.5 folds increase in expression of the CYP2E1 gene.

MS caused statistically significant growth of CYP3A2 mRNA expression at a group of pubertal animals (Fig. 2). Changes of CYP3A2 gene expression in adult animals with MS were not significantly different from control. Results on CYP3A2 mRNA expression investigation in the livers of pubertal and adult rats with MS and losartan administration demonstrated more pronounced changes at groups of young rats. Losartan, administered to pubertal animals with MS, increased the level of CYP3A2 mRNA expression. In adult animals, losartan did not cause statistically significant changes in the level of CYP3A2 mRNA expression.

In the case of CYP2C23, we detected a reduction of mRNA expression levels in livers of both age groups with MS as compared with controls: pubertal animals -1.4 folds, adults -1.6 folds (Fig. 3). Losartan administration allowed normalizing CYP2C23 mRNA expression rates only in the group of pubertal animals. In the group of adult animals, such losartan effect was absent.
We investigated the activity of PNP-hydroxylase in liver microsomes of adult and pubertal rats with MS and losartan administration. Statistically significant growth of PNP- hydroxylase activity with MS was detected both at pubertal ( 1.6 fold) and adult ( 1.38 fold) animals groups (Tab. 1).

Study of pubertal rats' microsomal PNP-hydroxylase activity with MS and losartan administration also generally matched data on CYP2E1 gene expression. In this group rate of PNP-hydroxylase activity was increased by 1.7 fold as compared with the control. Changes in PNP-hydroxylase activity in the liver microsomal fraction of adult animals with MS and losartal administration were opposite: normalization to the control levels.

The investigation of erythromycin- $\mathrm{N}$-demethylase activity showed MS opposite (by nature) effects in groups of pubertal ( 3 fold reduction) and adult animals (46\% increase). But losartan administration caused normalization of erythromycin-N-demethylase activities with MS irrespective of age.

Investigation of diclofenac-hydroxylase activity rates (Tab. 1) demonstrated its reduction with MS in rats of both age groups (more pronounced in adults). As in the case of erythromycin- $\mathrm{N}$-demethylase losartan administration led to normalization of diclofenac-hydroxylase activity rate in both age groups. 


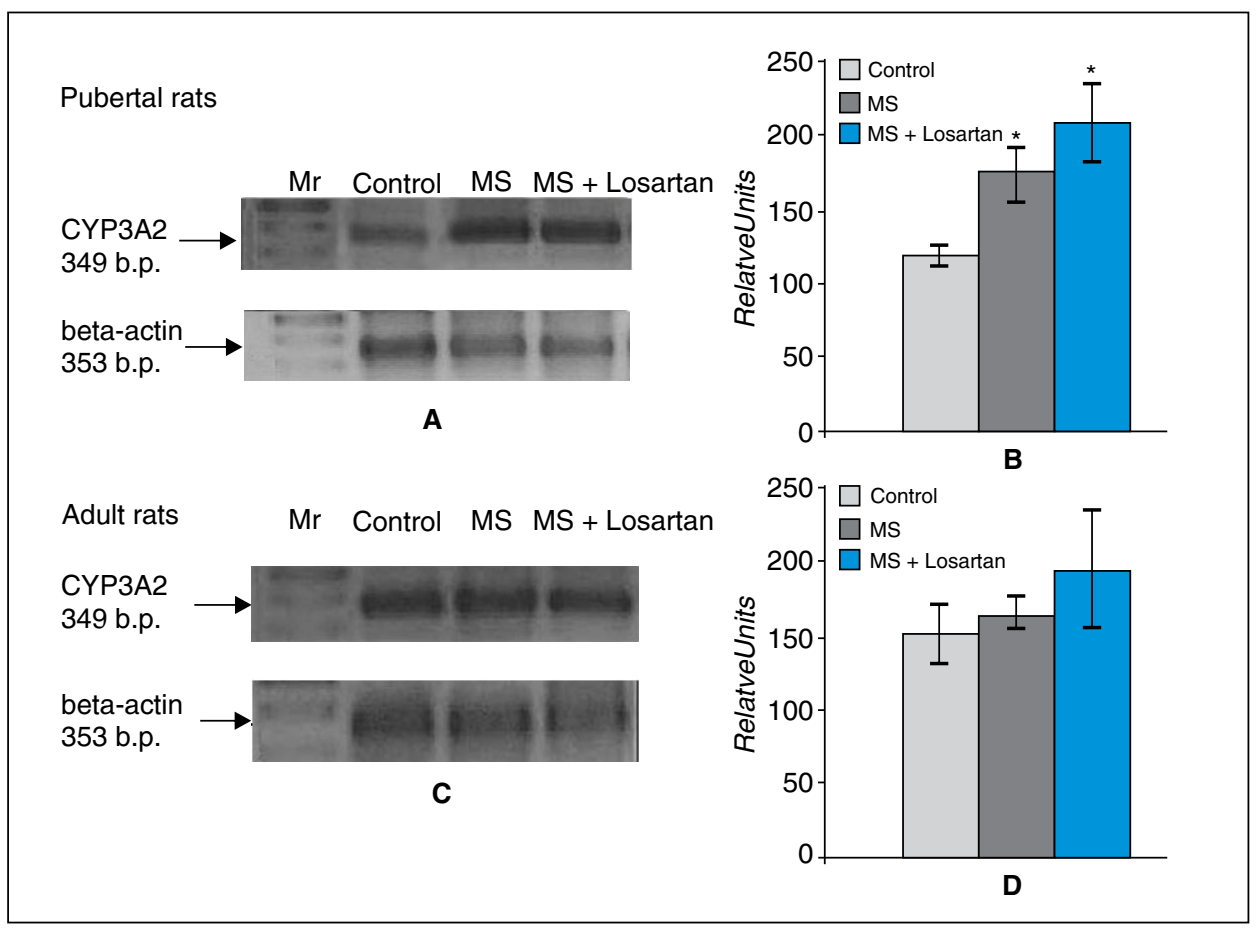

Figure 2. $C Y P 3 A 2$ mRNA content in the liver of pubertal and adult rats with MS and losartan administration: A, C - representative electrophoregrams of CYP3A2 (349 b.p) and reference-gene $\beta$-actin (353 b.p.) RT-PCR products; B, D - average rate of CYP3A2 mRNA expression in liver ( $\mathrm{n}=6, \mathrm{Mr}$ - DNA marker, signal intensity of $\beta$-actin was taken as $100 \%)$ ${ }^{*} \mathrm{P}<0.05$ in comparison with control

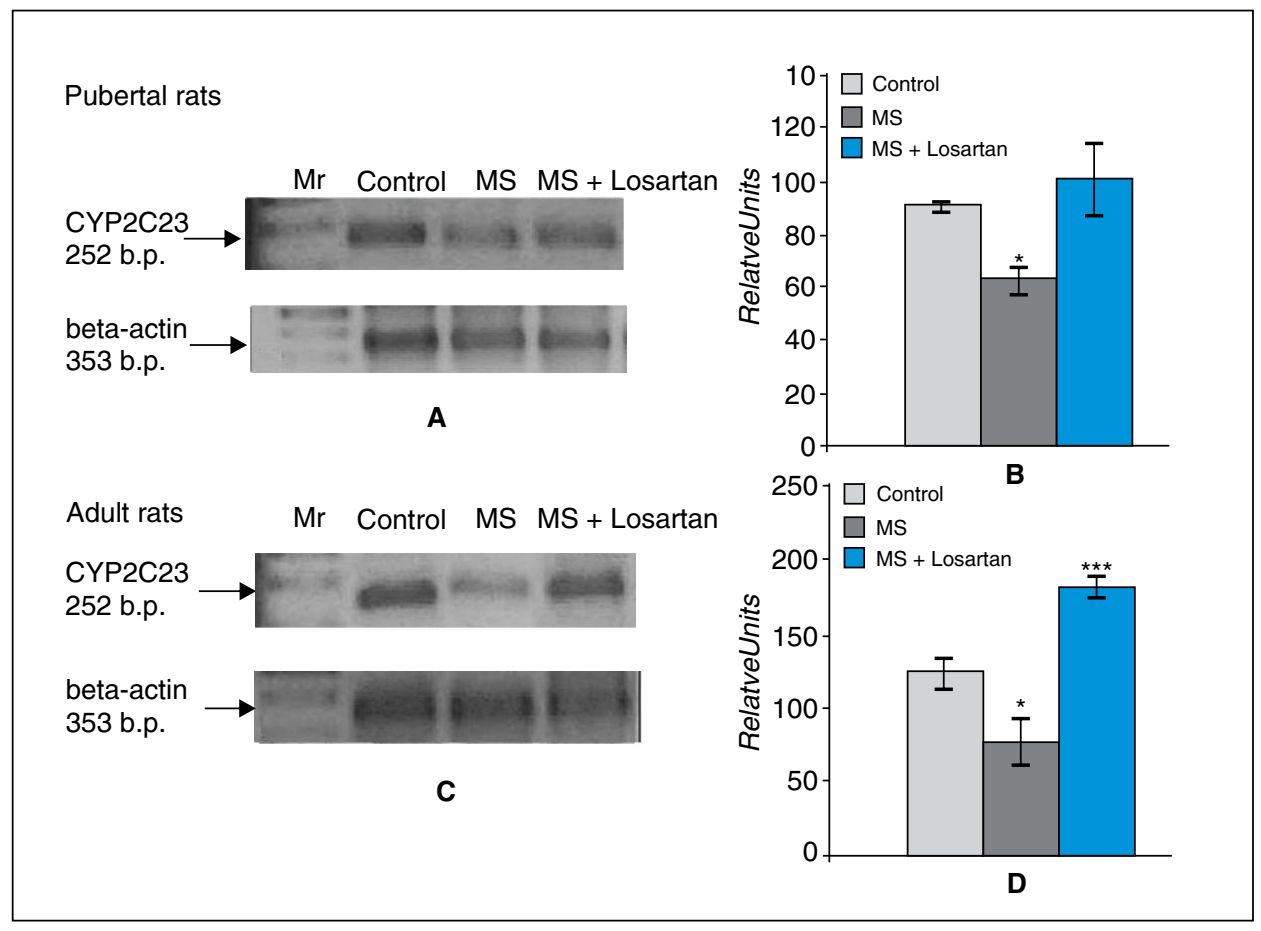

Figure 3. CYP2C23 mRNA content in the liver of pubertal and adult rats with MS and losartan administration: A, C - representative electrophoregrams of CYP2C23 (252 b.p) and reference-gene b-actin (353 b.p.) RT-PCR products; B, D - average rate of CYP2C23 mRNA expression in liver $(\mathrm{n}=6, \mathrm{Mr}$ - DNA marker, signal intensity of $\beta$-actin was taken as $100 \%$ ); ${ }^{*}<0.05$ in comparison with control; $* * P<0.05$ in comparison with MS 
Table 1. Activities of PNP-hydroxylase, erythromycin-N-demethylase and diclofenac hydroxylase in liver microsomal fraction of pubertal and adult rats $(M \pm S E M, n=6)$

\begin{tabular}{|c|c|c|c|}
\hline Groups & $\begin{array}{c}\text { Activity of PNP- hydroxylase, } \\
\text { nmoles } \times \mathrm{min}^{-1} \times \mathrm{mg}^{-1} \\
\text { protein }^{-1}\end{array}$ & $\begin{array}{l}\text { Activity of erythromycin- } \mathrm{N} \text { - } \\
\text { demethylase, }{\text { nmoles } \times \mathrm{min}^{-1}}^{-1} \\
\times \mathrm{mg}_{\text {of }} \text { protein }\end{array}$ & $\begin{array}{c}\text { Activity of diclofenac } \\
\text { hydroxylase, }{\text { nmoles } \times \mathrm{min}^{-1}}^{-1} \\
\times \mathrm{mg} \text { of } \text { protein }^{-1}\end{array}$ \\
\hline Control 1 & $0.46 \pm 0.021$ & $0.96 \pm 0.17$ & $552.0 \pm 19.1$ \\
\hline MS3 & $0.74 \pm 0.051^{*}$ & $0.32 \pm 0.09^{\star}$ & $380.2 \pm 13.8^{*}$ \\
\hline MS3 + losartan & $0,77 \pm 0,065$ * & $1,04 \pm 0,38$ & $568,8 \pm 161,0$ \\
\hline Control 2 & $0.45 \pm 0.018$ & $0.22 \pm 0.02$ & $403.6 \pm 14.8$ \\
\hline MS4 & $0.62 \pm 0.055^{\star *}$ & $0.32 \pm 0.03^{\star *}$ & $140.8 \pm 14.3^{\star *}$ \\
\hline MS4 + losartan & $0,44 \pm 0,040$ & $0,20 \pm 0,02$ & $576,7 \pm 93,5^{\#}$ \\
\hline
\end{tabular}

${ }^{*} \mathrm{P}<0.05$ in comparison with control $1 ;{ }^{*} \mathrm{P}<0.05$ in comparison with control 2 ; ${ }^{\#} \mathrm{P}<0.05$ in comparison with MS4

Table 2. Contents of reduced glutathione and glutathione transferase and reductase activities in liver of pubertal and adult rats with $M S(M \pm S E M, n=6)$

\begin{tabular}{|c|c|c|c|}
\hline Groups & $\begin{array}{l}\text { Activity of glutathione } \\
\text { reductase, } \text { nmoles } \times \mathrm{min}^{-1} \\
\times \mathrm{mg}^{-1} \text { of protein }\end{array}$ & $\begin{array}{l}\text { Activity of glutathione } \\
\text { transferase, } \mu \text { moles } \times \mathrm{min}^{-1} \\
\times \mathrm{mg}^{-1} \text { of protein } \\
\end{array}$ & $\begin{array}{l}\text { Contents of glutathione, } \\
\mu \text { moles } \times g \text { of tissue }{ }^{-1}\end{array}$ \\
\hline Control 1 & $109.8 \pm 4.6$ & $1.35 \pm 0.09$ & $2.28 \pm 0.33$ \\
\hline MS3 & $89.4 \pm 5.9$ * & $1.08 \pm 0.05$ * & $1.30 \pm 0.15^{\star}$ \\
\hline MS3 + losartan & $88,6 \pm 6,4$ * & $1,04 \pm 0,080$ * & $1,25 \pm 0,11^{*}$ \\
\hline Control 2 & $115.0 \pm 5.5$ & $1.25 \pm 0.09$ & $2.58 \pm 0.27$ \\
\hline MS4 & $114.0 \pm 5.0$ & $1.12 \pm 0.06$ & $1.48 \pm 0.18^{\star *}$ \\
\hline MS4 + losartan & $110,8 \pm 4,2$ & $1,04 \pm 0,059$ & $1,80 \pm 0,18^{* *}$ \\
\hline
\end{tabular}

${ }^{\star} \mathrm{P}<0.05$ in comparison with control $1 ;{ }^{*} \mathrm{P}<0.05$ in comparison with control 2

In our experiments, glutathione-S-reductase $(-18.5 \%)$, glutathione transferase $(-20 \%)$ activities and reduced glutathione contents (-43\%) were significantly decreased in pubertal rats with MS (Tab. 2). Losartan administration also caused a profound decrease in levels of glutathione-S-reductase, glutathione transferase and glutathione contents. In adults losartan administration with MS led only to glutathione contents decrease.

Simultaneously with changes in glutathione metabolism, LPO processes in rats liver cells were intensified (Tab. 3). This was indicated by the increased rates of NADPH-dependent thiobarbituric acid reactive substances production both in groups with MS and losartan administration with MS irrespective of age.

\section{Discussion}

It is absolutely obvious that to increase therapy's efficiency and safety it is necessary to have accurate CYP450 isoforms profile information in each individual case. It allows to establish the potential interaction of drugs, including competition for specific isoforms, the individual variability associated with high polymorphism of these isoforms, and different isoenzymes possible induction. Some of the pathologies including MS, obesity and diabetes could additionally modify profiles of CYP450 isoforms thus changing drugs effects. Unfortunately, such data are limited to several studies in adults, and specifics of metabolic processes in children and adolescents are generally not taken into account by researchers and clinicians [2, 3]. In view of the above, we have identified expression profiles of three isozyme CYP450 in the liver of pubertal rats and adult animals with MS and losartan administration.

Our results on the enhancement of CYP2E1 gene expression with MS are in agreement with other authors data, which showed an increase in CYP2E1 activity in laboratory animals with obesity, which is one of the main constituents of MS [19, 20]. Administration of losartan to pubertal and adult rats with MS did not lead to normalization of the CYP2E1 expression level in the liver. Regarding the p-nitrophenol hydroxylase (CYP2E1 marker enzyme), its activity increased in the group of pubertal rats both with MS and losartan administration with MS. This is consistent with the above findings of the CYP2E1 gene expression study. However, we have not registered changes in the $\mathrm{p}$-nitrophenol 
Table 3. NADPH-dependent LPO in rat liver microsomal fractions with $M S$ and losartan administration (M $\pm S E M ; n=6$;)

\begin{tabular}{lcc}
\hline Groups & NADPH-dependent LPO, nmoles $\times$ min $^{-1} \times$ mg of protein $^{-1}$ \\
\cline { 2 - 3 } & Pubertal rats & Adult rats \\
\hline Control & $0,078 \pm 0,007$ & $0,105 \pm 0,02$ \\
Metabolic syndrome & $0,170 \pm 0,04^{*}$ & $0,167 \pm 0,02^{*}$ \\
Metabolic syndrome +losartan & $0,133 \pm 0,016^{*}$ & $0,164 \pm 0,015^{*}$ \\
\hline
\end{tabular}

${ }^{\star} \mathrm{P}<0.05$ in comparison with control

hydroxylase activity in the microsomal fraction of adult rat liver. In this case, CYP2E1 expression intensification was not accompanied by the stimulation of the corresponding enzyme activity, as noted by other researchers in relation to various isoforms of CYP450 [21, 22]. Such age-dependent differences in losartan effects with MS might be due to changes in number, affinity, density, and/or subtypes of angiotensin I and II receptors [23-25].

The metabolism of losartan in the liver of rats also involves CYP2C and CYP3A isoforms [26-28]. The MS greatly affects the expression of the CYP3A2 gene (CYP3A4 orthologue) in the liver of pubertal rats, increasing its level by $30 \%$ compared with the control group. Regarding the erythromycin- $\mathrm{N}$-demethylase (CYP3A2 marker enzyme), its activity decreased in the group of pubertal rats with MS. Interestingly, other authors also showed a decrease in the clearance of CYP3A4 cytochrome substrates in obese patients compared to normal [21]. It could be evidence of this isoenzyme's activity decrease with this pathology. In our opinion, synchronous loss of CYP3A4 activity and its gene expression increasing might be in this case due to post-translational glycosylation. This process includes, besides the modification of enzyme's activity, changes of its localization in certain cellular compartments and start of proteasomal degradation processes [29]. Our assumption is confirmed by the data of enzymatic kinetics study of non-glycosylated and glycosylated isomyforms of CYP450 aromatase [30].

Losartan increased the expression level of $\mathrm{CY}$ P3A2 mRNA in pubertal rats, but the erythromycin-N-demethylase activity remained at the control level. This, obviously, could be explained by the complex interrelations of this drug simultaneous actions as a substrate and an inducer on the erythromycin-N-demethylase [31, 32]. Losartan affinity to CYP3A2 could be also changed with MS [33]. In adult rats with MS, administration of losartan resulted in the maintenance of both CYP3A2 expression and enzymatic activity at the control levels.

We demonstrated the reduced expression of $C Y$ P2C23 mRNA (ortholog CYP2C9 and CYP2C19) in the liver of pubertal rats with MS compared to controls. This can be entirely expected taking into account the particular sensitivity of CYP1A2, CYP2C19, and CYP3A4 iso- forms expression regulatory systems with liver pathological changes [34]. Although it should be noted that their activity may vary selectively, depending on the type of pathology [34]. Losartan administration under these conditions led to the normalization of this indicator: expression of the CYP2C23 gene in the liver of pubertal rats was at the same level as in the control group. The activity of diclofenac hydroxylase (CYP2C23 marker enzyme) also remained at the control level. Losartan, administered to adult rats, revealed increased both the level of CYP2C mRNA expression and the activity of diclofenac hydroxylase.

It should be noted (summarizing the results of CYP450 isoforms expression study), that significant variability in the expression rates of CYP3A and CYP2C genes is present in pubertal rats compared with adults with MS. Also, must be stressed the fact that losartan, administered to adult and pubertal rats, has different effects on CYP3A and CYP2C mRNA expressions regulation. While this drug did not correct CYP2C expression rate in the liver of adult rats with MS, it provided this indicator normalization in pubertal rats. Similarly, with respect to CYP3A, losartan had a much stronger effect on gene expression in pubertal rats.

Among profound changes in CYP450 isoforms expression rates, treated pathological processes, additionally, could significantly change rates of other biotransformation processes, which play the important role on drugs effects realization [19]. During the drugs biotransformation, not only biologically active and inactive metabolites are produced, but also cytotoxic reactive intermediates may appear [19]. The reactive metabolites formed as a result of the metabolism in the first phase of detoxification can be neutralized through reactions of the second phase, most a significant of which is the conjugation with the glutathione with the participation of S-transferase. In previous experiments, we showed that with metabolic syndrome at the same time as changes in certain cytochrome P-450 isoforms expression levels, deviations in the functioning of the glutathione system occur [4]. They differed significantly depending on the age of the experimental animals and were more profound in pubertal rats with MS.

Modulations of CYP450 system caused by MS and losartan administration are accompanied by the reduc- 
tion of antioxidant protection, which creates conditions for oxidative stress development. Our previous investigations of MS age-dependent effects showed more profound changes in reduced glutathione contents, as well as glutathione-S-transferase and reductase activities at pubertal animals, while at adults - only glutathione contents decreased [4]. Losartan administration didn't cause any normalizing effects on glutathione-system at both age groups. But in groups of pubertal animals negative effects of MS and losartan administration on glutathione-S-transferase and glutathione reductase were more pronounced. Our data on glutathione system changes are in accordance with other authors' results obtained in experiments in vivo [35-37].

The analysis of our own data and other authors' results allows suggesting that the antioxidant and anti-inflammatory effect of losartan in liver tissues [37] obviously is realized by the cytokine-mediated mechanism without involving glutathione system.

MS (according to our previous data) caused oxidative stress and stimulated lipid peroxidation [4]. These processes play important roles in MS development [38]. Losartan administration weakly suppresses levels of MS-induced lipid peroxidation. More pronounced this effect was in a group of pubertal animals. Our results are consistent with other researchers data [39]. These results could be an additional confirmation of our abovementioned suppositions on mechanisms of losartan antioxidant and anti-inflammatory effects in liver tissues.

\section{Conclusion}

Thus, losartan effectiveness towards normalization of CYP450 isoforms expression rates, p-nitrophenol hydroxylase, erythromycin- $\mathrm{N}$-demethylase and diclofenac hydroxylase activities (but not glutathione system and lipid peroxidation rates) depends on the age of experimental animals. The lack of information on the age characteristics of losartan effects on the CYP450 and glutathione systems states with MS makes this data particularly important. The obtained results are another confirmation of the need to optimize and individualize MS therapy, taking into account the age of the patient.

\section{Conflict of interest}

There is no financial or other relationships that might lead to a conflict of interest

\section{References}

1. Chu PY, Campbell MJ, Miller SG, et al. Anti-hypertensive drugs in children and adolescents. World J Cardiol. 2014; 6(5): 234-244, doi: 10.4330/wjc.v6.i5.234, indexed in Pubmed: 24944754.
2. Hirsch A, Hahn D, Kempná $P$, et al. Metformin inhibits human androgen production by regulating steroidogenic enzymes HSD3B2 and $\mathrm{CY}$ P17A1 and complex I activity of the respiratory chain. Endocrinology. 2012; 153(9): 4354-4366, doi: 10.1210/en.2012-1145, indexed in Pubmed: 22778212

3. Attia GR, Rainey WE, Carr BR. Metformin directly inhibits androgen production in human thecal cells. Fertil Steril. 2001; 76(3): 517-524, doi: 10.1016/s0015-0282(01)01975-6, indexed in Pubmed: 11532475.

4. Bondarenko LB, Shayakhmetova GM, Voronina AK, et al. Age-dependent features of CYP3A, CYP2C, and CYP2E1 functioning at metabolic syndrome. J Basic Clin Physiol Pharmacol. 2016; 27(6): 603-610, doi: 10.1515/jbcpp-2016-0012, indexed in Pubmed: 27371822

5. Iwamura A, Fukami T, Hosomi H, et al. CYP2C9-mediated metabolic activation of losartan detected by a highly sensitive cell-based screening assay. Drug Metab Dispos. 2011; 39(5): 838-846, doi: 10.1124/dmd.110.037259, indexed in Pubmed: 21321060

6. Choi DH, Li C, Choi JS. Effects of myricetin, an antioxidant, on the pharmacokinetics of losartan and its active metabolite, EXP-3174, in rats: possible role of cytochrome P450 3A4, cytochrome P450 2C9 and P-glycoprotein inhibition by myricetin. J Pharm Pharmacol. 2010; 62(7): 908-914, doi: 10.1211/jpp.62.07.0012, indexed in Pubmed: 20636879.

7. Abdulla MH, Sattar MA, Abdullah NA, et al. The contribution of $1 \mathrm{~B}-$ adrenoceptor subtype in the renal vasculature of fructose-fed Sprague-Dawley rats. Eur J Nutr. 2011; 50(4): 251-260, doi: 10.1007/s00394010-0133-8, indexed in Pubmed: 20882287

8. Kamath SA, Kummerow FA, Narayan K. A simple procedure for the isolation of rat liver microsomes. FEBS Letters. 2001; 17(1): 90-92, doi: 10.1016/0014-5793(71)80571-9.

9. Jäger W, Correia MA, Bornheim LM, et al. Ethynylestradiol-mediated induction of hepatic CYP3A9 in female rats: implication for cyclosporine metabolism. Drug Metab Dispos. 1999; 27(12): 1505-1511, indexed in Pubmed: 10570034

10. Imaoka S, Hashizume T, Funae Y. Localization of rat cytochrome P450 in various tissues and comparison of arachidonic acid metabolism by rat P450 with that by human P450 orthologs. Drug Metab Pharmacokinet. 2005; 20(6): 478-484, doi: 10.2133/dmpk.20.478, indexed in Pubmed: 16415532.

11. Koop D. Inhibition of ethanol-inducible cytochrome P 450 IIE1 by 3-amino-1,2,4-triazole. Chemical Research in Toxicology. 1990; 3(4): 377-383, doi: 10.1021/tx00016a017.

12. Wang RW, Newton DJ, Scheri TD, et al. Human cytochrome P450 3A4-catalyzed testosterone 6 beta-hydroxylation and erythromycin N-demethylation. Competition during catalysis. Drug Metab Dispos. 1997; 25(4): 502-507, indexed in Pubmed: 9107550

13. Nekrasova LV, Russkih YaV, Novikov AV, et al. Application of the method (HPLC-tandem high resolution MS) for the drug compounds determination in natural water. Scientific instrumentation [Nauchnoye priborostroenie. 2010; 20(4): 59-66.

14. Habig WH, Pabst M, akoby WB. Glutathione-S-Transferases. J. Biol. Chem. 1974; 249(22): 7130-7139.

15. Mannervik B, Jemth P. The Glutathione Pathway. Measurement of Glutathione Transferases. Costa LG, Hodgson E, Lawrence DA, Ozolins TR, Reed DJ, Greenlee WF, editors. Current Protocols in Toxicology. N. In: Costa LG, Hodgson E, Lawrence DA, Ozolins TR, Reed DJ, Greenlee WF. ed. Current Protocols in Toxicology. John Wiley \& Sons Inc, New York 2005: 2758.

16. Sedlak J, Lindsay RH. Estimation of total, protein-bound, and nonprotein sulfhydryl groups in tissue with Ellman's reagent. Anal Biochem. 1968; 25(1): 192-205, doi: 10.1016/0003-2697(68)90092-4, indexed in Pubmed: 4973948.

17. Lankford SM, Bai SA, Goldstein JA. Cloning of canine cytochrome P450 2E1 cDNA: identification and characterization of two variant alleles. Drug Metab Dispos. 2000; 28(8): 981-986, indexed in Pubmed: 10901710.

18. Stalnaya ID, Gharishvili TG. Method for malone dialdehyde determination with thiobarbituric acid. In: Orechovich VN. ed. Modern Methods in Biology. 66-68, Moscow 1997: 66-68.

19. Lucas D, Farez C, Bardou LG, et al. Cytochrome P450 2E1 activity in diabetic and obese patients as assessed by chlorzoxazone hydroxylation. Fundam Clin Pharmacol. 1998; 12(5): 553-558, doi: 10.1111/ j.1472-8206.1998.tb00985.x, indexed in Pubmed: 9794154

20. Dey A, Cederbaum Al. Induction of cytochrome P450 2E1 [corrected] promotes liver injury in ob/ob mice. Hepatology. 2007; 45(6): 1355-1365, doi: 10.1002/hep.21603, indexed in Pubmed: 17538970.

21. Brill MJE, Diepstraten J, van Rongen A, et al. Impact of obesity on drug metabolism and elimination in adults and children. Clin Pharmacokinet. 2012; 51(5): 277-304, doi: 10.2165/11599410-00000000000000, indexed in Pubmed: 22448619.

22. Oh SJ, Choi JM, Yun KUk, et al. Hepatic expression of cytochrome P450 in type 2 diabetic Goto-Kakizaki rats. Chem Biol Interact. 
2012; 195(3): 173-179, doi: 10.1016/j.cbi.2011.12.010, indexed in Pubmed: 22244987.

23. Crespo MJ, Altieri PI, Escobales N. Increased vascular angiotensin II binding capacity and ET-1 release in young cardiomyopathic hamsters. Vascul Pharmacol. 2006; 44(4): 247-252, doi: 10.1016/j. vph.2006.01.003, indexed in Pubmed: 16503205.

24. Wu JN, Edwards D, Berecek KH. Changes in renal angiotensin II receptors in spontaneously hypertensive rats by early treatment with the angiotensin-converting enzyme inhibitor captopril. Hypertension. 1994; 23(6 Pt 2): 819-822, doi: 10.1161/01.hyp.23.6.819, indexed in Pubmed: 8206610

25. Tsutsumi K, Strömberg C, Viswanathan M, et al. Angiotensin-II receptor subtypes in fetal tissue of the rat: autoradiography, guanine nucleotide sensitivity, and association with phosphoinositide hydrolysis. Endocrinology. 1991; 129(2): 1075-1082, doi: 10.1210/endo-129-2-1075, indexed in Pubmed: 1649738.

26. Stearns RA, Chakravarty PK, Chen R, et al. Biotransformation of losartan to its active carboxylic acid metabolite in human liver microsomes. Role of cytochrome P4502C and 3A subfamily members. Drug Metab Dispos. 1995; 23(2): 207-215, indexed in Pubmed: 7736913.

27. Shou M, Dai R, Cui D, et al. A kinetic model for the metabolic interaction of two substrates at the active site of cytochrome P450 3A4. J Biol Chem. 2001; 276(3): 2256-2262, doi: 10.1074/jbc.M008799200, indexed in Pubmed: 11054425.

28. Bae Jw, Choi Ci, Kim Mj, et al. Frequency of CYP2C9 alleles in Koreans and their effects on losartan pharmacokinetics. Acta Pharmaco Sin. 2011; 32(10): 1303-1308, doi: 10.1038/aps.2011.100, indexed in Pubmed: 21841812.

29. Aguiar M, Masse R, Gibbs BF. Regulation of cytochrome P450 by posttranslational modification. Drug Metab Rev. 2005; 37(2): 379-404, doi: 10.1081/DMR-46136, indexed in Pubmed: 15931769

30. Jo Corbin C, Mapes SM, Lee YM, et al. Structural and functional differences among purified recombinant mammalian aromatases: glycosylation, N-terminal sequence and kinetic analysis of human, bovine and the porcine placental and gonadal isozymes. Mol Cell Endocrinol. 2003; 206(1-2): 147-157, doi: 10.1016/s0303-7207(02)00422-7, indexed in Pubmed: 12943997.
31. Yang SH, Choi JS, Choi DH. Effects of HMG-CoA reductase inhibitors on the pharmacokinetics of losartan and its main metabolite EXP-3174 in rats: possible role of CYP3A4 and P-gp inhibition by HMG-CoA reductase inhibitors. Pharmacology. 2011: 88(1-2): 1-9, doi: 10.1159/000328773, indexed in Pubmed: 21709429

32. Yasar U, Sain-Guven G, Yardimci Y, et al. Effect of atorvastatin on CYP2C9 metabolic activity as measured by the formation rate of losartan metabolite in hypercholesterolaemic patients. Basic Clin Pharmacol Toxicol. 2011; 109(2): 73-77, doi: 10.1111/j.1742-7843.2011.00687.x, indexed in Pubmed: 21332946.

33. Taavitsainen P, Kiukaanniemi K, Pelkonen O. In vitro inhibition screening of human hepatic P450 enzymes by five angiotensin-II receptor antagonists. Eur J Clin Pharmacol. 2000; 56(2): 135-140, doi: 10.1007/s002280050731, indexed in Pubmed: 10877007.

34. Villeneuve JP, Pichette V. Cytochrome P450 and liver diseases. Curr Drug Metab. 2004; 5(3): 273-282, doi: 10.2174/1389200043335531, indexed in Pubmed: 15180496.

35. Murad HA, Gazzaz ZJ, Ali SS, et al. Candesartan, rather than losartan, improves motor dysfunction in thioacetamide-induced chronic liver failure in rats. Braz J Med Biol Res. 2017: 50(11): e6665, doi: 10.1590/1414-431X20176665, indexed in Pubmed: 28953991.

36. Ateyya $\mathrm{H}, \mathrm{Nader}$ MA, El-Sherbeeny NA. Beneficial effects of rosiglitazone and losartan combination in diabetic rats. Can J Physiol Pharmacol. 2018; 96(3): 215-220, doi: 10.1139/cjpp-2017-0332, indexed in Pubmed: 28892640

37. Czechowska G, Celinski K, Korolczuk A, et al. The effect of the angiotensin II receptor, type 1 receptor antagonists, losartan and telmisartan, on thioacetamide-induced liver fibrosis in rats. J Physiol Pharmacol. 2016; 67(4): 575-586, indexed in Pubmed: 27779478.

38. Roytberh HE. Metabolic syndrome. Scientific Digest. Science. MED-press-inform 2007: 224

39. Lin $\mathrm{CH}$, Yang $\mathrm{H}$, Xue QL, et al. Losartan improves measures of activity, inflammation, and oxidative stress in older mice. Exp Gerontol. 2014; 58: 174-178, doi: 10.1016/j.exger.2014.07.017, indexed in Pubmed: 25077714 